\title{
From University To School: Preparing Pre-Service Teachers For The Real World
}

Helen Huntly, (E-mail: h.huntly@cqu.edu.au), Central Queensland University, Australia

\begin{abstract}
Much of the literature on programs of pre-service teacher education highlights the disparity between what is learned at university and what is actually required in the classroom. This paper outlines a new philosophy of teacher training adopted by the Faculty of Education and Creative Arts at Australia's Central Queensland University. It describes the design, content and operation of a new practicum program, where in a unique partnership between the university and the education community in which it operates, supervising teachers are able to customise part of each practicum to suit the individual needs of the student teacher. This organisational feature is continued into a compulsory six-week Internship that is designed to enhance the education experience for each individual student teacher. The paper concludes with the preliminary findings of an investigation into what student teachers see as the major differences between their final practicum and the internship.
\end{abstract}

\section{INTRODUCTION}

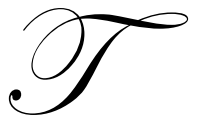

he focus of this paper is an examination of the professional practicum requirements of the Bachelor of Learning Management (BLM), Central Queensland University's recently introduced undergraduate teaching qualification. Although the Faculty of Education and Creative Arts at CQU has always valued the professional practicum component of existing teaching degrees, the new program prioritised the practical experiences of undergraduate teachers and enabled the development of a new 'prac' philosophy within the faculty and the education communities in which the practicum operates. With input from a wide cross-section of educators within the Central Queensland area, the BLM reinvented the way in which the professional practicum was conceived, prepared-for and administered. This paper provides the reasons for such change, outlines the new processes developed as integral to the practicum component of the BLM, and introduces the compulsory Internship program, devised as the final practical experience of the degree. The paper concludes with a presentation of preliminary findings from an investigation of how the Internship was experienced by the undergraduate teachers involved in the inaugural program.

\section{BACKGROUND}

Few would debate the rapid and significant change that has come to represent the modern world. Globalisation has facilitated unequalled technological advancement and uncertain political and economic conditions. As society struggles to adapt, traditional institutions such as work, education and family become particularly vulnerable (Giddens, 1999). The $21^{\text {st }}$ century is witness to shifting work patterns and high unemployment, as family structure undergoes reconfiguration from the nuclear family to more diverse social arrangements (Education Queensland, 2000). Just as family and employment trends evolve to accommodate contemporary society, so too must the social institution of schooling.

There is little disagreement that current systems of education do not reflect social change, nor do they adequately prepare learners for participation in flexible and adaptive life pathways (Wise \& Leibbrand, 2001). Education journals and tabloid newspapers alike reinforce a belief that current systems of education are failing to equip students with the knowledge and skills required for successful participation in and contribution to $21^{\text {st }}$ century 
society (Ramsay, 2000). Although political, economic and social practices continue to undergo constant change, the manner in which educators are prepared, has changed little in more than half a century (Abbott, 1999).

The Faculty of Education and Creative Arts at Central Queensland University agreed with the substantial research suggesting that education reform was not possible without a transformation of undergraduate teacher education (Fullan \& Hargreaves, 1992; Sanders \& Epstein, 1998). Apple (2001) noted that, although there had been numerous proposals to reform teacher training, none had proven adequate to the task. As a consequence, universities were coming under increased public scrutiny as they faced pressure to prepare teachers able to facilitate and manage the learning of an increasingly diverse and complex pool of learners (Ramsay, 2000). What was required, was a degree that did not merely prepare educators to teach, but alternatively, a qualification that ensured eductors were able to manage the learning of a range of individual students.

\section{BACHELOR OF LEARNING MANAGEMENT}

For several years now, education research has recommended that teacher preparation programs require substantial reconceptualisation to enable closer links to the real world of teachers (Bassett, 1978; Board of Teacher Registration, 1987; Eltis, 1991; Ramsay, 2000; Maxon \& Schwartz, 2001). Developments in the United Kingdom since the early 1990's included the establishment of a government directed Teacher Training Agency that has overseen the restructure of teacher education to a shared responsibility between universities and schools. Although this change has experienced challenges and setbacks, few would argue that such partnerships are highly appropriate (Cashdan, 1992).

Similar observations have been made in the USA, where poor student achievement prompted an urgent call to more closely link university and school experiences, so that student teachers gain a more accurate picture of current classroom conditions, whilst classroom teachers have input into the planning, implementation of programs of undergraduate teacher education (Maxon \& Schwartz, 2001). At the local level, Australian research over the past two decades, also produced several reports that recommend more functional partnerships between the university and the school (Luke \& Matters, 2002; Ramsay, 2002).

The Bachelor of Learning Management (BLM) was thus borne of a recognised need for change in the way teacher education was conceptualised and delivered. To begin this important process of change, it was decided that a team, representative of the education community, would be drawn together in a spirit of professional partnership. Along with faculty representatives, this team consisted of district education directors (executive directors of schools), principals, deputy principals and classroom teachers from Queensland State, Catholic and Independent education systems. The team also consulted with the Queensland Teachers Union and Board of Teacher Registration, the organisation responsible for the formal registration of qualified teachers in the State of Queensland.

In conceiving the BLM, the team sought guidance from the research of Smith (2000) and Luke and Matters (2000) who suggest that contemporary teachers must be equipped with knowledge, skills and discourses required for 'new times'. They must be able to link curriculum, pedagogy and assessment, whilst developing more effective ways to talk about and attend to equity and student diversity. The BLM planning team was irrevocably bound by a shared vision to link learning experiences to the operational context of the learners, thus ensuring that schools remained meaningful and relevant.

\section{EDUCATION COMMUNITY PARTNERSHIPS}

Wise and Leibbrand (2001) argue that teacher educators must reinvent themselves in order to improve learning outcomes for students. Similarly, Sealy, Robson and Hutchins (1997) propose a program that promotes student teacher development in authentic contexts, and initiates and fosters partnerships with the learning communities in which the graduating teacher will operate.

For several years, educational researchers have suggested that the key to the transformation of teacher preparation is in the development and maintenance of authentic partnerships with the school community (Bottey, 
1996; Sinclaire, 1997; Cochran -Smith, 1998; Battersby \& Ebbutt, 1999; Maxon \& Schwartz, 2001). This concept has been taken up in the United Kingdom where, since the early 1990's school-based teacher education programs have flourished in a climate where teachers are considered equal partners with universities, in the provision of pre-service programs (Board of Teacher Registration, 1994). Similarly in the USA, the establishment of Professional Development Schools has enabled the teaching profession to advance, through a focus on quality university and school partnerships.

Similarly, Australian universities have to keep pace with social and economic demands. In response to such demands, the National Board of Employment, Education and Training (1990) suggests that the pre-service education of teachers should integrate theory and practice in a holistic way through the utilisation of contextual learning sites. This aim can only be achieved with the cooperative effort of both the university and the school. In Queensland the story is much the same. Since the 1970's a steady stream of research and reports has recommended a closer working relationship between the providers of education and the providers of teacher education (Bassett, 1978; Project 21, 1987; Eltis, 1991; Seaby, Robson \& Hutchins, 1997).

The pedagogical challenge posed by educational researchers was to strengthen the relevant aspects of the preservice program to provide student teachers with a more realistic view of schools, whilst equipping them with real world knowledge and skills. Aitken and Mildon (1992) argue for a fundamental rethink of teacher education where practical experiences are developmentally linked to courses and university experiences. This is a notion reinforced by Bezzina $(1999$, p. 2) who demands that providers of teacher education "seriously address the dichotomy between what is learnt at university and the realities in schools".

\section{PROFESSIONAL PRACTICUM IN THE BLM}

Motivated by a desire to more authentically link the theoretical elements of university courses to the real world of the classroom, the BLM enabled the faculty to facilitate a fundamental rethink of the manner in which teacher education students were prepared for and participated in the practicum. The new degree has its emphasis on (and financial investment in) best pedagogical practice, both at university and at school. It also 'practises what it teaches' in terms of catering for the diverse needs of a broad range of undergraduate 'learners'. Inherent in this rebirth of the 'prac' is the notion that the best practice in terms of teacher preparation does not necessarily mean that technology plays a major role. In fact for BLM students, all of whom attend university on an internal (face-to-face) basis, a conscious decision was made to invest heavily in 'warm body' technology, where students are taught, mentored and supervised by a range of industry-current university and school teachers, all of whom are aware and supportive of their individual learning needs. To this end, students will be guided by a series of experienced university and school personnel.

Each practicum is preceded by an extensive course of preparatory lectures and tutorials that cover important aspects of the work of teachers. Students are provided with detailed insights into teaching elements including handwriting, planning, classroom management, ethical behaviour and reflective practice. Tutorials allow students to experience various teaching and management issues through focussed micro-teaching sessions. Students are familiarised with the requirements of the prac and are made aware of exactly what will be expected of them. Assessment and 'at risk' procedures are also covered. Lecturers of other courses within the same term as the practicum are also involved through their efforts to link important elements of their courses (eg Key Learning Areas), to practicum experiences. In fact, several courses include an assessment task that is devised or implemented during the practicum, ensuring that student teachers write units or deliver classes in the context for which they are planned.

The 'warm body' technology is continued in the relationships that are developed and maintained with the school personnel who act as Learning Managers (supervising teachers) for the student teachers. All Learning Managers are inducted into the program so that they are aware of the BLM and its philosophical underpinnings. Before, during and after the prac, school personnel are consulted and kept informed about all elements of their involvement in the partnership. 
The final 'warm body' involved in the practicum is perhaps the most vital to its success. At the inception of the BLM it was decided that, in response to research demanding closer links between universities and the education sites in which the practicum is offered, schools would become true partners in the learning journey of student teachers. As a consequence, the role of University Learning Coordinator (ULC) was devised and adopted. Based on the traditional model of 'prac supervisors', these industry-current teachers (many on leave from teaching positions or working part time) are brought into the team of individuals who manage the learning of students whilst on prac. At the pre-prac meeting, ULC's are advised of the requirements of the prac and the names of the students and Learning Managers whose rooms they will visit. ULC's then arrange to meet students at university and organise a site-based meeting of Learning Managers. They continue their supervision with regular classroom visits and are available for consultation by the student or the Learning Manager, by request. The final duty of the ULC is to attend a post-prac debriefing meeting where they share ideas regarding potential improvement of the prac, feedback from the school and details of any areas of concern in relation to the progress of the student teacher. These details can then be used for the planning of future practicum experiences of particular students.

\section{CUSTOMISATION OF THE PRACTICUM}

In keeping with the BLM ethos of individualising the learning journey for students, built into each practicum is a period of time towards the end of the prac, where an individual learning plan is devised for each student teacher. In consultation with the Learning Manager, the student teacher will set her own requirements for a specific timeframe. This plan (usually for the final week of prac) will allow the student teacher to concentrate on and perhaps 'practise' those operations or routines in which they are not yet competent or confident. In contrast to the traditional 'one size fits all' approach to practicum requirements, this model provides the flexibility required when catering for a diverse range of student teacher interests, capabilities and needs. It has the added benefit of encouraging the Learning Manager to become more aware of the strengths and weaknesses of the student teacher's pedagogical and communication skills, and thus accept more ownership of the practicum.

The Learning Managers involved in the BLM report a heightened sense of the importance of their role in the professional development of tomorrow's teachers. The model also serves to strengthen the cooperative partnership between the university and the education community in which it operates. In the spirit of this partnership and with the belief that the Learning Manager should be integrally linked to the learning plan of the student teacher, a compulsory Internship provides an opportunity for the development and implementation of the ultimate individual learning plan.

\section{INTERNSHIP}

In a departure from the traditional requirements of the faculty's Bachelor of Education program, the BLM includes a compulsory six-week internship during the final year of study. The Internship is designed to commence at the conclusion of the student teacher's final practicum and is placed so that student teachers are located in schools for the entire third term of the school calendar. As the preferred model enables the student teacher to remain in the same class for the internship, as allocated for the final prac, relationships and routines are already well established, ensuring every opportunity for successful outcomes for all participants.

The notion of an internship as the final extended period of in-school experience for student teachers was planned in response to the considerable Australian research highlighting the positive aspects this form of culminating practicum (Hatton, 1996; Ballantyne, Green, Yarrow \& Millwater, 1999; Cameron, 2001; Mayer, 2002). Keeping in mind the recommendation that internships are rarely enriching when the university and the school are treated as unrelated entities (Hatton, 1996), the BLM Internship was designed in partnership with the education community and at all times, effort is made to use university time to prepare students for the real world of the classroom. Internship briefing meetings are also held for mentors (Learning Managers) and interns (student teachers), with University Learning Coordinators continuing to play an important linking role between university and school. Researchers such as Mayer (2002) stress the importance of this face-to-face interaction between the interns and university representatives so a conscious decision was made to continue the work of the ULC into the internship. 
Pre and post internship briefing sessions were convened for all participants in the program. Before the commencement of the internship, mentors and interns met with faculty practicum staff to be briefed on aspects such as the role of the university and the school, expectations, insurance, provisional registration, legal matters and assessment expectations. More specific to this paper, the same people were reconvened (at separate meetings) at the conclusion of the program, where data was gathered in relation to a number of aspects involved in the internship. What is reported here are some preliminary findings of research that is being conducted by practicum staff in relation to the outcomes of the initial BLM internship program. For the purposes of this study, data was gathered through surveys and focus group interviews with the interns involved in the inaugural program.

Although only preliminary analysis has been possible at this stage, early findings suggest that the internship provides a highly positive experience for participating interns. For the purpose of the research presented here, attention will focus on a question that sought these interns' perceptions of the differences (if any) between the professional practicum (initial four weeks) and the internship (final six weeks). Participants were asked to respond the question "What did you see as the major differences (if any) between the final prac and the internship?" Analysis of the collected responses suggests that interns experience subtle changes in a number of elements in the transition from practicum to internship. The following section of this paper outlines these perceptions.

\title{
PRELIMINARY FINDINGS
} include:

Interns report an increase in intern confidence once the final prac is complete. Participants' comments

\author{
- $\quad$ My personal confidence increased, do doubt! \\ - I I was so much more confident during the internship. \\ - $\quad$ There was something different about how I felt in the internship - like I had suddenly grown all this \\ confidence.
}

Interns also reported an increased sense of ownership of the learning environment during the Internship, with comments as follows:

- I was given a great amount of freedom to try different approaches and strategies which was greatly appreciated. It felt more like MY class once the prac had finished.

- I $\quad$ was able to develop strong and positive rapport with the class. It felt like MY class - which is not a feeling you can develop readily in four weeks.

Interns who participated in this study also commented on the different manner in which they were treated in the school, once the final practicum was complete. Participants mentioned a subtle change of attitude towards them, by existing school personnel. Interns made comments such as:

- $\quad$ Yes - a major difference was the change of attitude from other staff - they were more relaxed with us.

- $\quad$ [After the prac] I was taken on as a co-teacher. The school saw me and communicated with me as if I was a full time teacher.

- $\quad$ The teachers' approaches seemed to completely change and they accepted me 'into their club' as a teacher.

- $\quad$ During the Internship I was treated as a fellow teacher, my opinion was sought in matters relating to the classes I taught and I was given authority to sign behaviour slips.

The final theme alluded to by interns was their experience of the relationship changes that occurred once the practicum had concluded and the Internship begun. In experiencing this change in the relationship base, interns suggested that there was a definite change in the way they were 'looked upon' by the school community once the Internship had commenced. Comments include the following: 
- $\quad$ I suddenly had more respect from students, teachers and parents.

- When I was an intern, the students accepted me as a part of their class, the staff acknowledged that I was there for more than a few weeks and I really felt part of the school community.

\section{DISCUSSION}

Preliminary analysis of the interns' survey and focus group transcripts reveals a number of shared perceptions of the differences between the final practicum and the internship. In response to a question aimed at the elicitation of interns' perceptions of the difference between the final professional practicum and the internship, interns emphasised their growth in confidence once the transition from student to intern was complete. Interns described a sense of assuredness that was not evident during the practicum. It could be argued that this new confidence may be linked to the second perception reported by interns. A greater sense of ownership was experienced by interns once the final practicum was complete. This ownership was described in terms of the interns' willingness to take control of the learning environment and to try a variety of approaches in managing the classroom.

Interns agreed further that the internship bore witness to an attitudinal change towards them, from most sectors of the school community. Participants in this study reported an unprecedented acceptance of interns into the teachers' 'club' that was not evident during the practicum. This theme of professional acceptance may be linked to the final theme revealed through data analysis. Interns described a situation where, at the commencement of the internship, a series of relationship changes was evident. Interns noted that their pupils viewed them as 'real' teachers more readily during the internship than at any time during the practicum. Accordingly, this relationship change initiated a new respect from pupils, teachers and parents. At this stage, the Internship program seems to be achieving the expected outcomes; however, further analysis will refine these findings and enable a more comprehensive discussion of the perceptions of interns in relation to the differences between the final practicum and the internship. Future studies will seek the perceptions of mentors in order to compare their responses to those of the interns who share their classrooms.

\section{CONCLUSION}

Although still in the early stages, evidence from this study suggests that the internship program is a worthwhile experience for final year teacher education students. Student teachers involved in the study describe several positive outcomes from the six-week program and generally speak highly of their internship experiences. Of interest to the research presented here, is the notion that subtle changes occur when the student teacher makes the transition to intern. The changes revealed through this study include:

\section{- $\quad$ Greater confidence of the intern}

- $\quad$ More ownership of the learning environment by the intern

- $\quad$ Attitudinal change towards the intern by teachers, students and parents

- Change in the relationship base between mentors and interns, from that of student-teacher to one of teacherteacher

Preliminary findings suggest that a compulsory internship provides several benefits that are unable to be experienced through the traditional practicum. Further research of this important area of undergraduate teacher education, however, will reveal additional knowledge about the effect of internship participation to the overall preparation of teachers. This knowledge will allow more informed decisions to be made when planning and implementing undergraduate teacher education programs that will most effectively prepare the workforce for Australian schools. 


\section{REFERENCES}

1. Abott, J. (1999). "Battery Hens or Free Range Chickens: What type of education for what type of world?" Keynote address, North of England Education Conference, Sunderland.

2. Aitken, J. L. \& Mildon, D. A. (1992). "Teacher Education and the Developing Teacher: The role of personal knowledge". In Fullan, M. \& Hargreaves, (Eds.), A. Teacher Development and Educational Change. London: Falmer Press.

3. Apple, M.W. (2001). "Markets, Standards, Teaching and Teacher Education", Journal of Teacher Education, 52, 3, 182-196.

4. Ballantyne, R., Green, A., Yarrow, A. and Millwater, J. (1999). "Reciprocal mentoring: Preparing learning materials for teacher development". Teacher Development, 3, 1, 79-94.

5. Bassett, G. W. (1978). "Teacher Education in Queensland". Report of the Committee appointed by the Board of Advanced Education and the Board of Teacher Registration, Brisbane, Queensland.

6. Battersby, J. \& Ebbutt, D. (1999). "Aspects of Quality in Institutional Training in Ethiopia and the UK: Comparing notes, questions and issues". Paper presented at British Educational Research Association Annual Conference, University of Sussex, Brighton.

7. Bezzina, C. (1999). "Teacher Education Reform in Malta: Establishing partnerships with students". Paper presented at European Conference on Educational Research, Lahti, Finland.

8. Board of Teacher Registration, Queensland. (1987). "Project 21: Teachers for the $21^{\text {st }}$ Century". Toowong, Queensland.

9. Board of Teacher Registration, Queensland. (1994). "Report of the Working Party on the Practicum in Preservice Teacher Education". Toowong, Queensland.

10. Botty, M. (1996). "The Challenge to Professions for the New Public Management: Implications for the teaching profession". Oxford Review of Education, 22, 2, 179-195.

11. Cameron, R. B. (2001). "Identifying the developmental phases encountered by beginning teachers during an internship". Australian Association for Research in Education Conference, 2-6 December, 2001. Fremantle, Western Australia.

12. Cashdan, A. (1992). "The New Partnership: Initial teacher training in the UK". Paper presented at the International Council on Education for Teaching, World Assembly, Paris.

13. Cochran-Smith , M. (1998). "Teacher Development and Educational Change". In Hargreaves, A., Liebermann, A., Fullan, M. and Hopkins, D. (Eds.), International Handbook of Educational Change. Boston: Kluwer Academic Publications.

14. Education Queensland, (2000). "2010 Queensland State Education”. The State of Queensland. Department of Education.

15. Eltis, K. (1990). "Reshaping Preservice Teacher Education: Establishing a practicum driven curriculum". Journal of Teaching Practice, 11, 2, 1-17.

16. Fullan, M. and Hargreaves, A. (1992). "Teacher Development and Educational Change". London: Falmer Press.

17. Giddens, A. (1999). "Runaway World Lecture", Reith Lectures, BBC, London.

18. Hatton, E. (1996). "The state of field experience in Australia". Australian Association for Research in Education Conference, 25-29 November, 1996, Singapore.

19. Luke, A. and Matters, G. (2000). "The New Basics, Facets of Change Conference Papers". The State of Queensland, Department of Education.

20. Mayer, D. (2002). "An electronic lifeline: Information and communication technologies in a teacher education internship". Asia Pacific Journal of Teacher Education, 30, 2, 181-195.

21. Maxon, S. and Schwartz, D. (2001). "School - University Collaboration for Reform in California: The DELTA Project". The Clearing House, 74, 5, 251-256.

22. National Board of Employment, Education and Training (1990). "Australia's Teachers: An agenda for the next decade". Canberra: Australian Government Publishing Service.

23. Ramsay, G. (2000). "Quality Matters Revitalising Teaching: Critical times, critical choices". Report of the Review of Teacher Education. New South Wales Department of Education. 
24. Sanders, M.G. and Epstein, J. L. (1998). "School - Family - Community Partnerships and Educational Change: International Perspectives”. In Hargreaves, A., Liebermann, A., Fullan, M. and Hopkins, D. (Eds.), International Handbook of Educational Change. Boston: Kluwer Academic Press.

25. Sealey, R., Robson, M. and Hutchins, T. (1997). "School and University Partnerships: Some findings from a curriculum development project". Asia Pacific Journal of Teacher Education, 25, 1, 70-89.

26. Sinclair, C. (1997). "Redefining the Role of University Lecturer in School-Based Teacher Education". Asia Pacific Journal of Teacher Education, 25, 3, 309-324.

27. Smith, R. (2000). "The Future of Teacher Education: Principles and prospects". Asia Pacific Journal of Teacher Education, 28, 1, 7-28.

28. Wise, A.E. and Liebbrand, J.A. (2001). "A Statement from NCATE: Standards in the new millennium: Where we are, where we are headed". Journal of Teacher Education, 52, 3, 244-255.

\section{NOTES}

